\title{
Strategizing the Port of Libreville to Serve as a Gateway Port
}

\author{
Mondjo Mouckagni Raymond Stanis, Jie Gao \\ College of Transport and Communication, Shanghai Maritime University, Shanghai, China \\ Email: davidsmondjo@yahoo.fr
}

How to cite this paper: Stanis, M. M. R., \& Gao, J. (2019) Strategizing the Port of Libreville to Serve as a Gateway Port Technology and Investment, 10, 59-79.

https://doi.org/10.4236/ti.2019.104004

Received: November 21, 2019

Accepted: November 27, 2019

Published: November 30, 2019

Copyright (C) 2019 by author(s) and Scientific Research Publishing Inc. This work is licensed under the Creative Commons Attribution International License (CC BY 4.0).

http://creativecommons.org/licenses/by/4.0/

\begin{abstract}
This paper aims to apply Data Envelopment Analysis (DEA) method for measuring and getting the ranking position between Cameroon and Gabon port over 4 other ports in the west and central Africa to compare the efficiency of those two ports and having their current ranking position for eight years (2010-2017) between them over the other ports. After that, use System Dynamic (SD) to forecast the future container cargo throughput by invest in port and improve the level of services of Gabon port, for it is able to become a gateway port of central Africa.
\end{abstract}

\section{Keywords}

System Dynamic, DEA, Gateway, Efficiency

\section{Introduction}

Started last century with the augmentation of the size of the world population also the increasing size of international trade with the percentage of exchanges between different countries around the world, the maritime sector is one of the significant sectors involved in this economic growth by the fact that more than $70 \%$ of the goods are transported by sea. All the African countries are involved in this economic growth and more are the countries with seaports, but most of the African ports can be considered as the entrance door of the economies of the countries or the area, at the same time as the barrier of the country's or areas development. Most of the African ports are not efficient to affect the economy of the countries, which is also the case of Owendo port (Gabon) where the inefficiency of the port is negatively affecting the economic activities when it was supposed to boost the economy.

Today ports are more considered as the main entry and exit of international exchange of economic activities of a country hence they must integrate new 
technology to enhance performance and the ability to compete with other ports around the world to attract more activities.

Nowadays, African ports are big as some European ports and have the same facilities and a huge number of container throughput productivity rate. Notwithstanding they still play a minor role in international trade, when the global export has been broken down to 3\% in 2014 for Africa, 32\% from Asia and 36.8\% from Europe during the World Trade Organization, 2015.

Most of the West and Central African ports today have become familiar with the transformation of the major players in the maritime industry. This is because all these big companies are obliged to serve their customers around the world in all markets. Today the African market cannot be avoided to be taken into consideration when for example in 2011 it came with around 2.63 million TEUs from which 0.70 million TEUs were from Europe and 1.92 million TEUs from Asia.

We can also see that was a continuous growth in TEUs within the region in the subsequent years. In 2014 it increased to 3.31 million TEUs which is $26 \%$ growth in three years and further increased in 2015 to 630 million TEUs in international trade across the globe. Having a growth in tonnage of $134 \%$ between 2009 to 2014 passing through Lagos Port and 100\% to Pointe Noire port (Isemar, 2016), this can be considered as a testimony to real dynamic growth.

The drive for Africa container traffic is due to the growth of the world economy and the upgrading of the facilities in the maritime sector.

The facilities in African ports today are advanced as compared to past years. This has greatly enhanced technical capabilities, and the advent of mobile cranes and quay cranes has sped up handling considerably. 25 years ago, without proper port facilities, four or five containers could be processed in an hour, whereby today 15 containers are processed on average. Despite considerable progress, the development of African ports is still being hampered by numerous problems.

Libreville (Owendo) is the more important of the two maritime gateways in Gabon as it handles 75 per cent of the country's commercial trade, while further south Port-Gentil is the first exit opportunities for infrastructural development. The achievements include the acquisition of an automatic identification system and vessel traffic services system to better regulate port activities and a significant reduction of vessel waiting time through the streamlining of administrative processes. To highlight this last point, in 2009, vessel waiting times could reach 15 days, whereas today it is 48 hours.

The efficiency of the port facilities provides more value and this will affect the port's overall activities, at the same time adding value to its operations. The cost will be less and the time spent will be shot, which can also attract stakeholders from other neighboring countries to use Gabon port when the logistics transportation system is good.

Port efficiency is accounted for by many aspects of the port industry, whereby all the sectors of the port's operations are involved in the result of that efficiency. The efficiency also includes the transportation system of cargo arriving or leav- 
ing the port which plays a significant role in the movement of containers. All this today is possible with the advancement in technology which is playing a significant role in facilitating each task on the port operations procedure as compared to the last century. Today all ports, first and second are affected by the world's economy caused by the exchange in trades between different countries and continents made through the ports, which are considered as the door of entrance and exit of exchange.

The purpose of this article is to determine the potential Owendo Port of Gabon has and how it can be used to become more competitive and serve as a gateway port of The Economic and Monetary Community of Central African States (CEMAC) (Kingsleychenikwi \& Wang, 2018), amongst which two are hinterland countries and depends on neighboring countries ports. To be able to determine the current performance efficiency of Owendo port, we will compare her performance with three other ports of Central Africa and two ports of West Africa base on some characteristics and performance. After that, we will determine the potential of Owendo port of Gabon and how it can be used to improve her performance and become a model and a gateway port.

System Dynamic method is going to be used at the end to help us determine if Libreville port can serve as a gateway port to attract more clients from other countries or not. This article is divided as follows:

1. Introduction

2. Literature Review

3. Methodology

4. Data Analysis

4.1. Efficiency

4.2. The use of System Dynamic

4.3. Handling Price

4.4. Dwell Time

5. Recommendations and Conclusions

\section{Literature Review}

The fact that the existence of maritime industry is growing more and more, at the same time with the world economy it is affecting almost all the activities of the ports around the world, including African ports, which motivated many peoples to write on ports performance using DEA as a tool of measuring the efficiency. The evaluation of port efficiency involves the comparison between different ports base on some indicator value, take into consideration over a specified period (Notteboom, 2010). The study of the efficiency, of eleven Portuguese ports between 1990 from 2000 were using DEA for they are total productivity as an asset, which include technical efficiency and technological evolution divided by different factors take into consideration the different evolutions (Martin \& Roman, 2001). Only the technical improvement efficiency was suggested and identified in all ports without any change concerning the technology.

The development of (DEA) Data Envelopment Analysis model has been made 
by Charnes et al. (Cullinane \& Wang, 2007), adding many input or output to DEA is one of the advantages of the model, which also give a possibility to provide an overall evaluation of port performance (Roll \& Hayuth, 1993). The technique of DEA has been applied to many various contexts since the introduction of the model by Charnes et al. (Cullinane \& Wang, 2007). One of the most appropriate and analytically indicators for the measurement of the port effectiveness is contenders' throughputs, with benchmarks like berths, length, the total area of the berths, storage as many time it has been used between the sea and inland transportation or transshipment quay cranes where it considers as a very critical for the port operations. The measurement of the port is not only the result of a perfect management system but also an essential tool of input for regional and national port planning and operations under the competition where it has been evaluated by the cargo handling calculated in relation with the berth (Tabernacle, 1995).

The evaluation of major ports around the world on their efficiency has been done in container seaports over a certain time by the study of (Cullinane, Song, Ji, \& Wang, 2004). The performance of a port over time has been demonstrated by the window analysis and the relative performance of that port in comparison to the others at the same time, where the efficiency of 11 ports have been calculated by using DEA over four years, Min and Park (Min \& Park, 2008), the data applied included total quay length, cranes, labour number, storage space, which were under the input data and cargo throughput under the output.

The DEA method is the most popular approach non-parametric methodology and the most parametric methodology used is SFA approach, on container study, and the majority of studies used DEA, the results and data confirm that DEA is the adequate approach to measure the efficiency of the container port. Schoyen (Schøyen \& Odeck, 2013), also concludes that DEA is adequate and more popular than SFA and is recently studied for more literature.

We can also see that container throughput (TEUs) most of the time is the output, variable used for the efficiency measurement of the port in most of the previous studies and the input used are physical variables (Bichou, 2013). For the measurement efficiency in the ports sector, we have different methods to use the parametric and nonparametric, for the first part of our case study on DEA, we are only going to focus on the efficiency of the container ports to keep the capability of comparing the results.

System Dynamic was developed by MIT professor Jay Forrester in 1950s and introduced in his book "Industrial Dynamics" in 1961, System Dynamics employ systems thinking's and complement it with rigorous modelling and formal computer simulations. It allows us to enhance the learning of complex systems and understand underlying sources of the problem (Sterman, 2011), Systems Dynamic originate from interactions between the model's elements. According to (Suryani, 2012) conventional forecasting methods face some problem that is covered by System Dynamic (Sterman, 2011), System Dynamic model is a software which helps us to study the size of the population, rate of births, the effi- 
ciency of distribution warehouse and transportation and the maritime area where it deals with an aspect like port efficiency performance.

A port's efficiency today contributes to the economy of its country in ways that will attract more ships to call to that port and serve the country or even the region. That has been the case for many ports in the USA, Europe, Asia and Africa. Thus why we think that Libreville port can be seen as an opportunity for the economy of the country as it has been for some other ports.

The port is part of the national and the regional economy, and they contribute to the gross national GDP and per capital income as other industries. Moreover, ports provide employment opportunities and taxes for the central and local government (Park \& Lim, 2012).

Most of the African ports are still lacking modern infrastructures which affects their performance and efficiency, this is caused by the lack of investment by the private and public sector. However, there is a significant investment that has been made carried out by the French company Bollore and also Maersk with other major shipping lines in many African countries that have helped to improve on port infrastructures and performance (Kingsleychenikwi \& Wang, 2018).

The regional centre as an evaluation factor is defined as a seaport having a good location combined with the attributions of deviation from the main routes and ports accessibility (Gi-Tae, Michael, \& John, 2011). The geographical system would involve from the first pattern of scattering, poorly connected ports along the coastline to the main network consisting of a corridor between gateway port major's hinterland centres (Notteboom, 2010), the evolution of the maritime industries and the actual competitiveness in the augmentation of the maritime industries. The system of the gateway is capturing a more significant share of traffic, based on the fact that smaller port tended to grow faster (Rodrigue \& Guan, 2009), the hinterland is not only being served by the ports of one gateway region but by several multi-ports gateway regions (Notteboom, 2010). The selection of the port call is made base on specific criteria relating to the market hinterland access as well as the quality of port infrastructure port gaining or losing port call base on a significant variation of its traffic (Rodrigue \& Guan, 2009). Dues to their unique geographical location and function port have attractive, products and cohesive function to the industry (Li \& Wang, 2013).

The disadvantages of the use of Libreville ports is the size of the population, which is around 1.5 million peoples, and even the GDP is growing the activities will still be based on the local need. The government can use that situation like an advantage base on the free trade zone created recently in Central Africa by the CEMAC composed of 6 countries where Gabon is part, this free trade zone stipulates that for exchanges in trading between the six countries the taxes are cheaper and for products made by these countries are tax free $(0 \%)$ when imported by any of the countries within the region.

System Dynamic will be used to forecast the container throughput base on the future investment and the adjustment of the port as a potential gateway port. 
These two models are going to illustrate this research.

All the supports reviewed elements which are going to be used to conduct this research is going to be taken from the internet, other relevant research publication, e-journal, Port reviews and Maritime magazines, textbooks and theories of experts.

\section{Methodology}

DEA model is going to be used in our research paper for the measurement of the exact current efficiency of Owendo port Gabon compare to Douala port Cameroon and System Dynamic for the planning of future investment to improve the efficiency of the Owendo port and increase its capacity by the right future sector of port investment. All the supports reviewed elements which are going to be used to conduct this research are going to be taken from the internet, other relevant research publication: e-journal, Port reviews and Maritime magazines, textbooks and theories for experts.

Three terminals area activities are located in Libreville ports, which are, containers, dry bulk cargo and crude oil. For our study, we are going to focus on the containers terminals for measuring the efficiency and analyze how Libreville port can increase his capacity and at the same time become more efficient to become a gateway port of central Africa.

Our research study is going to be the focus on the current efficiency of the port, and the actual reason of some inefficiencies and how to fix it by the future investment on the specific sector of port operating activities that include container yard capacity, ship turnaround time, terminal handling port, hinterland containers storage.

The evaluation of port efficiency performance has several methods which include regression analysis for example (Tongzon, 1995), where we know that many alternatives exist for the evaluation of measurement of efficiency made by comparing different indicator values for some specific ports given over some time.

(DEA) Data Envelopment Analysis has been invented by Charnes et al. (1978) (Cullinane \& Wang, 2007).

DEA is a method of measuring the efficiency of a unit referred to a decision-making unit (DMU) (Cullinane, Wang, \& Cullinane, 2004).

It has the ability to identify the best practice of DMU without a knowledge of input and outputs which are the most important to determine the measurement of efficiency or inefficiency for the other factors of DMU regarding the best practices (Leki, 2014).

DEA is a non-parametric method which is not based on the conclusion on technology. However, it can be derived from any method parametric, the possibility of providing any general equation relating to input or output, a DEA problem of no standard errors is the result of the LP solution, any inefficiency from DEA is treated as a deviation frontier (Cullinane, Wang, \& Cullinane, 
2004).

Input and output are the essential knowledge to determine the measurement of efficiency or inefficiency for all the DMU, other factors that are considered as the best practice of DMUs (Leki, 2014).

$$
\begin{gathered}
\operatorname{Max} \frac{\sum_{k=1}^{s} u_{k} y_{k p}}{\sum_{j=1}^{m} v_{i} x_{i p}} \\
\text { S.t. } \frac{\sum_{k=1}^{s} u_{k} y_{k i}}{\sum_{j=1}^{m} v_{j} x_{j i}} \leq 1 \forall i \text {, and } u_{k} v_{j} \geq 0 \forall k, j
\end{gathered}
$$

where

$$
\begin{aligned}
& y_{k i}=\text { amount of output } \mathrm{k} \text { produced by DMUi, } \\
& x_{j i}=\text { amount of input } \mathrm{j} \text { utilized by DMUi } \\
& u_{k}=\text { weight given to output } k, \\
& v_{j}=\text { weight given to intput } j . \\
& \max \sum_{k=1}^{s} u_{k} y_{k p}=\theta_{p} \\
& \text { Subject to } \sum_{j=1}^{m} v_{j} y_{j p}=1 \\
& \sum_{k=1}^{s} u_{k} y_{k i}-\sum_{j=1}^{m} v_{j} x_{j i} \leq 0 \forall i, u_{k}, v_{j} \geq 0 \forall k, j
\end{aligned}
$$

The fact that window analysis is very useful for measuring the port performance efficiency over a certain period on each port will be used for the case of determining the exact current efficiency of Gabon port over five others and compare it with Cameroon port.

After the measurement of the efficiency of Owendo port, we will use System Dynamic to forecast the container throughput.

The fact that the System Dynamic has been used previously in the improvement of ports performances many times with the complexity of the port, it proves to be a suitable model to be used.

Also, the fact that System Dynamic modelling discovers and represents systems through feedback processes, along with stock and flow structure, time delays and non-linearity, there is no set rule for successful modelling, but successful modelers tend to follow a disciplined process introduced by (Sterman, 2011), the fact that the system dynamic consists of a system.

$$
d x(t) / d t=f(x, p)
$$

where $x$ is a vector of level (stocks or state variables), $p$ is a set of parameters and $f$ is a nonlinear vector-valued function.

The simulation carried out, its value calculated through numerical integration, by splitting time into discrete intervals of length, System Dynamic is the state approach (Miguel, 2012).

In other words, the value of the state variables after computation depends not only on their net rate of change $x(t)$, but also on the previous values $x(t-d t)$, those state variables presented. 


$$
x(t)=x(t-d t)+x(t-d t) d t
$$

The system of couples has been solving in order of different equations, where the initial condition is to determine the solution in line with the notion of feedback on System Thinking, the fact is, that system determines its future evolutions and not just some external input with no regard for the system conditions itself (Miguel, 2012).

The typical application of the System Dynamic is in policy analysis and design, the concept of endogenous change is fundamental to the System Dynamics approach. Exogenous disturbances are seen at most as triggers of system behaviours (Richardson, 2011), the structure of the system itself is the causes of behaviours.

The research is going to analyze each step of container port process for a container to arrive or leave the port base on the time schedule which can result in the equipment available and the capacity of the container yard. The efficiency of a port can be defined by the work for a container at the port and also the cost of the service charges, this study aims to bring Libreville port as the choice number one in that area and for that, an analysis efficiency of other ports are made.

\section{Data and Analysis}

\subsection{Efficiency Comparison over 6 Africa Ports of West and Central Africa}

Port efficiency is the result of the container's port infrastructure productivity which is the key to a perfect system of management services performance. The ports were selected base on their region first (west and central) Africa and the container throughput above 100,000 TEUs (Van Dyck, 2015), but also one port per country where we can have two ports with a capacity of over 100,000 TEUs/year.

For this study, the factors have been chosen base on the fact of the difficulty of having access to various data information on the maritime field to conduct our research study efficiently, also, all the factors selected are uniform for all the ports used for the study.

First, we are going to compare Douala port (Cameroon) with Owendo port (Gabon) port by measuring their efficiency and late see how to improve the performance of Owendo port by increasing the container throughput and also providing a good quality of service by using System Dynamic for the port to become a gateway port of central Africa.

The efficiency over four other ports of the west and central Africa to have the exact current permeance of Gabon port compare to Cameron port and how they perform using annual container throughput.

The container throughput is finding in Table 1, where is show that Nigeria port has the highest number of annual containers throughput 2010 to 2017 continually, and in our particular case between Douala port Cameroon and Owendo port Gabon ports it shows that Gabon has a high number of containers throughput over the same period. 
Table 1. Input and output of study ports.

\begin{tabular}{|c|c|c|c|c|c|c|c|c|c|}
\hline & container throughput & 290,000 & 340,000 & 340,000 & 340,000 & 340,000 & 340,000 & 340,000 & 387,000 \\
\hline & Total quay length & 660 & 660 & 660 & 660 & 660 & 660 & 660 & 660 \\
\hline \multirow{6}{*}{$\begin{array}{l}\text { Port of Douala } \\
\text { (Cameroon) }\end{array}$} & Terminal area (ha) & 26 & 26 & 26 & 26 & 26 & 26 & 26 & 26 \\
\hline & Number of quayside crane & 2 & 2 & 2 & 2 & 2 & 2 & 2 & 2 \\
\hline & Number yard gantry cranes & 2 & 2 & 2 & 2 & 2 & 2 & 2 & 2 \\
\hline & Number of reach stackers & 14 & 14 & 14 & 14 & 14 & 14 & 14 & 14 \\
\hline & container throughput & 355,000 & 355,000 & 355,000 & 355,000 & 355,000 & 355,000 & 355,000 & 386,950 \\
\hline & Total quay length & 800 & 800 & 800 & 800 & 800 & 800 & 800 & 800 \\
\hline \multirow{6}{*}{$\begin{array}{l}\text { Port of Pointe } \\
\text { noire (Congo) }\end{array}$} & Terminal area $(\mathrm{ha})$ & 17 & 17 & 17 & 17 & 17 & 17 & 17 & 17 \\
\hline & Number of quayside crane & 4 & 4 & 6 & 6 & 6 & 6 & 6 & 6 \\
\hline & Number yard gantry cranes & 2 & 2 & 2 & 2 & 2 & 2 & 2 & 2 \\
\hline & Number of reach stackers & 26 & 26 & 26 & 26 & 26 & 26 & 26 & 26 \\
\hline & container throughput & 355,000 & 442,800 & 518,000 & 518,000 & 518,000 & 518,000 & 518,000 & 550,000 \\
\hline & Total quay length & 775 & 775 & 775 & 775 & 775 & 775 & 775 & 775 \\
\hline \multirow{6}{*}{$\begin{array}{c}\text { Port of } \\
\text { Owendo (Gabon) }\end{array}$} & Terminal area (ha) & 12 & 12 & 12 & 12 & 12 & 12 & 12 & 12 \\
\hline & Number of quayside crane & 2 & 2 & 2 & 2 & 2 & 2 & 2 & 2 \\
\hline & Number yard gantry cranes & 2 & 2 & 2 & 2 & 2 & 2 & 2 & 2 \\
\hline & Number of reach stackers & 10 & 10 & 10 & 10 & 10 & 10 & 10 & 10 \\
\hline & container throughput & 643,100 & 813,900 & 881,200 & 900,000 & 890,000 & 900,000 & 900,000 & 921,000 \\
\hline & Total quay length & 574 & 574 & 574 & 574 & 574 & 574 & 574 & 574 \\
\hline \multirow{6}{*}{$\begin{array}{c}\text { Port of } \\
\text { Tema (Ghana) }\end{array}$} & Terminal area (ha) & 10 & 10 & 10 & 10 & 10 & 10 & 10 & 10 \\
\hline & Number of quayside crane & 6 & 6 & 8 & 8 & 8 & 8 & 8 & 8 \\
\hline & Number yard gantry cranes & 4 & 4 & 13 & 13 & 13 & 13 & 13 & 13 \\
\hline & Number of reach stackers & 10 & 10 & 23 & 23 & 23 & 23 & 23 & 23 \\
\hline & container throughput & $1,232,000$ & $1,510,900$ & $1,723,000$ & $1,580,000$ & $1,700,000$ & $1,400,000$ & $1,437,000$ & $1,656,000$ \\
\hline & Total quay length & 1005 & 1005 & 1005 & 1005 & 1005 & 1005 & 1005 & 1005 \\
\hline \multirow{4}{*}{$\begin{array}{c}\text { Port of } \\
\text { Apapa (Nigeria) }\end{array}$} & Terminal area (ha) & 55 & 55 & 55 & 55 & 55 & 55 & 55 & 55 \\
\hline & Number of quayside crane & 10 & 10 & 10 & 10 & 10 & 10 & 10 & 10 \\
\hline & Number yard gantry cranes & 12 & 12 & 12 & 12 & 12 & 12 & 12 & 12 \\
\hline & Number of reach stackers & 31 & 31 & 31 & 31 & 31 & 31 & 31 & 31 \\
\hline \multirow{7}{*}{$\begin{array}{c}\text { Port of } \\
\text { Lome (Togo) }\end{array}$} & container throughput & 339,900 & 352,700 & 288,500 & 311,500 & 380,800 & 380,800 & 380,800 & 240,000 \\
\hline & Total quay length & 430 & 430 & 430 & 430 & 430 & 430 & 430 & 430 \\
\hline & Terminal area $(\mathrm{ha})$ & 12 & 12 & 12 & 12 & 12 & 12 & 12 & 12 \\
\hline & Number of quayside crane & 4 & 4 & 6 & 6 & 6 & 6 & 6 & 6 \\
\hline & Number yard gantry cranes & 0 & 0 & 0 & 0 & 0 & 0 & 0 & 0 \\
\hline & Number of reach stackers & 19 & 19 & 19 & 19 & 19 & 19 & 19 & 19 \\
\hline & variable & 2010 & 2011 & 2012 & 2013 & 2014 & 2015 & 2016 & 2017 \\
\hline
\end{tabular}

Source: (www.Bollore-port.com).

All the factors of inputs and outputs selected are critical for the analysis of the efficiency of the port where all affect their performance. The container port production reflects the inputs and outputs as much as possible (Cullinane, 
Wang, \& Cullinane, 2004).

For the efficiency, containers throughput are the primary output data used which remain to be the most and primary essential factor for all the ports compared, with the complementary of the other factors to obtain the efficiency performance (Table 2, Figure 1).

The size of ship call port, depending on the quay length side of the port which can be seen or considered as a significant indicator of port performance, for that quay length in a general view, Nigeria port has the highest one. Comparing Cameroon port and Gabon port it shows that the size of Gabon port is higher than Cameroon port, which can be seen as an advantage and the only way to solve it is to invest by increasing the size of the quay length. Today the maritime industry is influenced by the apparition of the mega big ship, which can be a problem for the future if Gabon port cannot call most of them (Table 1).

Nigeria port has the highest number of cranes, which is also reflected in the number of container throughput (Table 1, Table 3). Compare the number of cranes between Cameroon port and Gabon port and see which one has the highest number and assume that, this number is the result of the number of container throughput handled a year.

\section{Variation by Term}

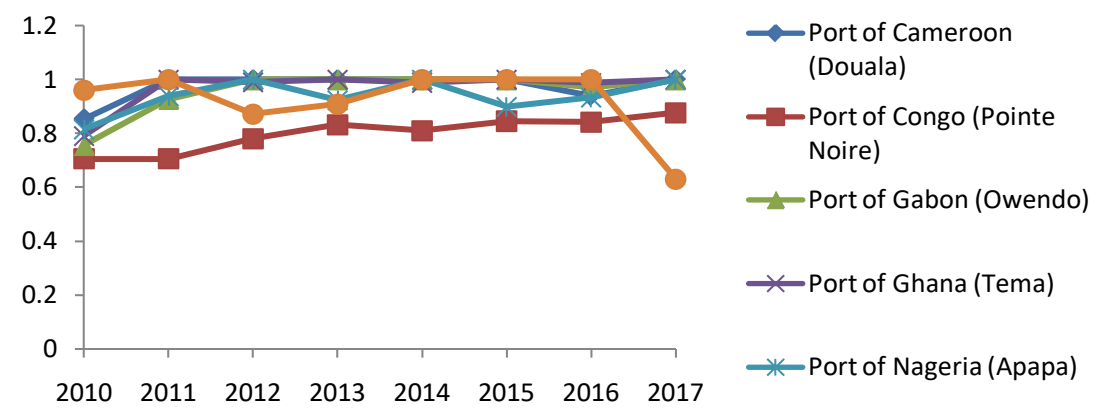

Figure 1. The fluctuation of container throughput by using DEA.

Table 2. Container throughput for selected port 2010-2017.

\begin{tabular}{ccccccccc}
\hline Average by Term & 2010 & 2011 & 2012 & 2013 & 2014 & 2015 & 2016 & 2017 \\
\hline $\begin{array}{c}\text { Port of Cameroon } \\
\text { (Douala) }\end{array}$ & 0.852941176 & 1 & 1 & 0.9696382 & 0.969638243 & 0.959518 & 0.939276 & 1 \\
$\begin{array}{c}\text { Port of Congo } \\
\text { (Pointe Noire) }\end{array}$ & 0.70564704 & 0.70564704 & 0.738481 & 0.7521475 & 0.752147484 & 0.767648 & 0.798648 & 0.86453 \\
$\quad \begin{array}{c}\text { Port of Gabon } \\
\text { (Owendo) }\end{array}$ & 0.646718147 & 0.854826255 & 1 & 0.9854545 & 0.985454545 & 0.980606 & 0.970909 & 1 \\
$\quad \begin{array}{c}\text { Port of Ghana } \\
\text { (Tema) }\end{array}$ & 0.79014621 & 1 & 0.979111 & 0.9942997 & 0.9832519 & 0.9924 & 0.988599 & 1 \\
$\quad \begin{array}{c}\text { Port of Nigeria (Apapa) } \\
\quad\end{array}$ & 0.715031921 & 0.876900754 & 1 & 0.9201069 & 0.989988392 & 0.816201 & 0.839652 & 0.974118 \\
Port of Togo (Lome) & 0.96115679 & 1 & 0.757616 & 0.8180147 & 1 & 1 & 1 & 0.630252 \\
\hline
\end{tabular}


Table 3. Summary statistics for our study ports.

\begin{tabular}{ccccccc}
\hline & $\begin{array}{c}\text { Total Quay } \\
\text { Length }\end{array}$ & $\begin{array}{c}\text { Terminal } \\
\text { Area }\end{array}$ & $\begin{array}{c}\text { Number of } \\
\text { Quayside Cranes }\end{array}$ & $\begin{array}{c}\text { Number of Yard } \\
\text { Gantry Cranes }\end{array}$ & $\begin{array}{c}\text { Number of } \\
\text { Reach Stackers }\end{array}$ & $\begin{array}{c}\text { Container Throughput } \\
\text { (TEUs) }\end{array}$ \\
\hline Max & 1005 & 55 & 10 & 13 & 31 & 1723000 \\
Min & 430 & 4 & 2 & 0 & 12 & 288500 \\
Average & 707.3333 & 20.66667 & 5.333333 & 6.5 & 20.83333 & $684,283.3333$ \\
SD & 181.9814 & 16.76968 & 2.981424 & 5.283622 & 6.618577 & $504,803.8577$ \\
\hline
\end{tabular}

From the period of the following years (2012, 2013, 2014, 2015, 2017), Douala port (Cameroon) and Owendo port (Gabon), have been performing at the same rate, but for the years $(2010,2011)$, port has a greater average in DEA efficiency while for the year 2016 Owendo port has got a greater average in terms of DEA efficiency compared to Douala port, hence we conclude that between 2010 to 2017, 2016was the only year that Owendo's port average DEA efficiency was greater than Douala port.

We can assume that base on this factor that the port of Douala (Cameroon) is performing better than Owendo port (Gabon) though the difference is not very high between them as seen in Table 4 .

From the efficiency of the six ports, we found out that the port of Douala in Cameron is the most efficient port as compared to the other ports from the period 2010 to 2017, and Pointe Noire port of Congo is the most inefficiency port from our study at the same period.

However, out of this general ranking over the six ports of our analysis, we found out that, Douala port of Cameroon comes on the first position when Owendo port of Gabon comes on the $3^{\text {rd }}$ position of our ranking for the period of 2010 to 2017.

This show that Douala port of Cameroon is more efficient compares to Owendo port of Gabon which means Owendo port must improve its port performance and service quality to become a gateway port and attract more peoples who use Douala port of Cameroon.

Also noted that the most inefficiency port of our ranking is the port of Pointe Noire (Congo), which is located in central Africa and already considered as a potential direct competitor of Owendo port of Gabon and Douala port of Cameroon in the regional economic trade (Table 4, Table 5).

We cannot just be focused on the number of containers throughput a year, the number of cranes ... etc. To assume or conclude that a port is an efficient port (Table 6), however, we also have to consider the standard quality of service provided by the port. The fact that Apapa port (Nigeria) is the largest port in terms of size and also has the highest number of container throughput yearly from the period of 2010 to 2017 comes on the $4^{\text {th }}$ position of our ranking efficiency (Table 5).

To the specific study, it shows that Douala port of Cameroon is performing well and better and Owendo port of Gabon must invest not only in the equipment's but also in port service provide, if it wants to achieve his objective of becoming a gateway port of central Africa. 
Table 4. Window analysis results.

\begin{tabular}{|c|c|c|c|c|c|c|c|c|c|c|}
\hline & 2010 & 2011 & 2012 & 2013 & 2014 & 2015 & 2016 & 2017 & Average & $\begin{array}{c}\text { C- } \\
\text { Average }\end{array}$ \\
\hline \multirow[t]{7}{*}{ Port of Cameroon (Douala) } & 0.852941 & 1 & & & & & & & 0.926471 & \\
\hline & & 1 & 1 & & & & & & 1 & \\
\hline & & & 1 & 1 & & & & & 1 & \\
\hline & & & & 1 & 1 & & & & 1 & \\
\hline & & & & & 1 & 1 & & & 1 & \\
\hline & & & & & & 1 & 1 & & 1 & \\
\hline & & & & & & & 0.878553 & 1 & 0.939276 & 0.980821 \\
\hline \multirow[t]{7}{*}{ Port of Congo (Pointe Noire) } & 0.705647 & 0.705647 & & & & & & & 0.705647 & \\
\hline & & 0.705647 & 0.705647 & & & & & & 0.705647 & \\
\hline & & & 0.854877 & 0.854877 & & & & & 0.854877 & \\
\hline & & & & 0.809803 & 0.809803 & & & & 0.809803 & \\
\hline & & & & & 0.809803 & 0.809803 & & & 0.809803 & \\
\hline & & & & & & 0.880608 & 0.880608 & & 0.880608 & \\
\hline & & & & & & & 0.803736 & 0.876072 & 0.839904 & 0.800899 \\
\hline \multirow[t]{7}{*}{ Port of Gabon (Owendo) } & 0.756549 & 1 & & & & & & & 0.878275 & \\
\hline & & 0.854826 & 1 & & & & & & 0.927413 & \\
\hline & & & 1 & 1 & & & & & 1 & \\
\hline & & & & 1 & 1 & & & & 1 & \\
\hline & & & & & 1 & 1 & & & 1 & \\
\hline & & & & & & 1 & 1 & & 1 & \\
\hline & & & & & & & 0.941818 & 1 & 0.970909 & 0.968085 \\
\hline \multirow[t]{7}{*}{ Port of Ghana (Tema) } & 0.790146 & 1 & & & & & & & 0.895073 & \\
\hline & & 1 & 1 & & & & & & 1 & \\
\hline & & & 0.979111 & 1 & & & & & 0.989556 & \\
\hline & & & & 1 & 0.988889 & & & & 0.994444 & \\
\hline & & & & & 0.988889 & 1 & & & 0.994444 & \\
\hline & & & & & & 1 & 1 & & 1 & \\
\hline & & & & & & & 0.977199 & 1 & 0.988599 & 0.980302 \\
\hline \multirow[t]{7}{*}{ Port of Nigeria (Apapa) } & 0.815408 & 1 & & & & & & & 0.907704 & \\
\hline & & 0.876901 & 1 & & & & & & 0.93845 & \\
\hline & & & 1 & 0.917005 & & & & & 0.958503 & \\
\hline & & & & 0.929412 & 1 & & & & 0.964706 & \\
\hline & & & & & 1 & 0.823529 & & & 0.911765 & \\
\hline & & & & & & 0.974252 & 1 & & 0.987126 & \\
\hline & & & & & & & 0.867754 & 1 & 0.933877 & 0.943161 \\
\hline \multirow[t]{7}{*}{ Port of Togo (Lome) } & 0.961157 & 1 & & & & & & & 0.980578 & \\
\hline & & 1 & 0.817976 & & & & & & 0.908988 & \\
\hline & & & 0.926164 & 1 & & & & & 0.963082 & \\
\hline & & & & 0.818015 & 1 & & & & 0.909007 & \\
\hline & & & & & 1 & 1 & & & 1 & \\
\hline & & & & & & 1 & 1 & & 1 & \\
\hline & & & & & & & 1 & 0.630252 & 0.815126 & 0.93954 \\
\hline
\end{tabular}


Table 5. Port efficiency ranking for some ports of the west and central Africa.

\begin{tabular}{ccc}
\hline Ports & Average Score & Rank \\
\hline Port of Douala & $0.98 \%$ & 1 \\
Port of Tema & $0.98 \%$ & 3 \\
Port of Owendo & $0.96 \%$ & 4 \\
Port of Apapa & $0.94 \%$ & 5 \\
Port of Lome & $0.93 \%$ & 6 \\
\hline
\end{tabular}

Table 6. Average port efficiency through each fourth years window.

\begin{tabular}{|c|c|c|c|c|}
\hline $\begin{array}{l}\text { Average through } \\
\text { Window }\end{array}$ & & & & \\
\hline & 2010-2011-2012-2013-2014 & 2011-2012-2013-2014-2015 & 2012-2013-2014-2015-2016 & 2013-2014-2015-2016-2017 \\
\hline $\begin{array}{l}\text { Port of Cameroon } \\
\text { (Douala) }\end{array}$ & 0.970588235 & 1 & 1 & 0.902842377 \\
\hline $\begin{array}{l}\text { Port of Congo } \\
\text { (Pointe Noire) }\end{array}$ & 0.70564704 & 0.70564704 & 0.80414899 & 0.807423511 \\
\hline $\begin{array}{l}\text { Port of Gabon } \\
\text { (Owendo) }\end{array}$ & 0.90030888 & 0.970965251 & 1 & 0.953454545 \\
\hline $\begin{array}{l}\text { Port of Ghana } \\
\text { (Tema) }\end{array}$ & 0.951629242 & 0.9936 & 0.9936 & 0.979587405 \\
\hline $\begin{array}{l}\text { Port of Nigeria } \\
\text { (Apapa) }\end{array}$ & 0.899117818 & 0.918618688 & 0.910040627 & 0.914470588 \\
\hline $\begin{array}{l}\text { Port of Togo } \\
\text { (Lome) }\end{array}$ & 0.907357409 & 0.91512605 & 0.91512605 & 0.889653361 \\
\hline
\end{tabular}

\subsection{The Use of System Dynamic to Model the Port for Future Investment}

The container terminal capacity is affected by the container cargo throughput. Moreover, if the terminal is not fully utilized, the more there is space available which is not used. This situation reflects the service quality provided by the port authority and make the port less attractive, the more the port becomes less attractive, the more the number of container throughputs will decrease, this relationship is the result of port management performance.

When the port demand increases, they always adjust that capacity base on the possibility they have. When this situation occurs, the port authority always feels the need for a new investment strategy on the capacity to be able to respond to the actual and future demand, thus, the current service quality is always compared with the standard service quality to determine the need for new investment.

The standard container terminal capacity utilization gives the port service quality base on the model build in our case (Figure 2(a), Figure 2(b)), which let's assume that the port demand and performance can be calculated based on the occupancy and the user of all the port facilities, as a berth, yard, terminal storage. 


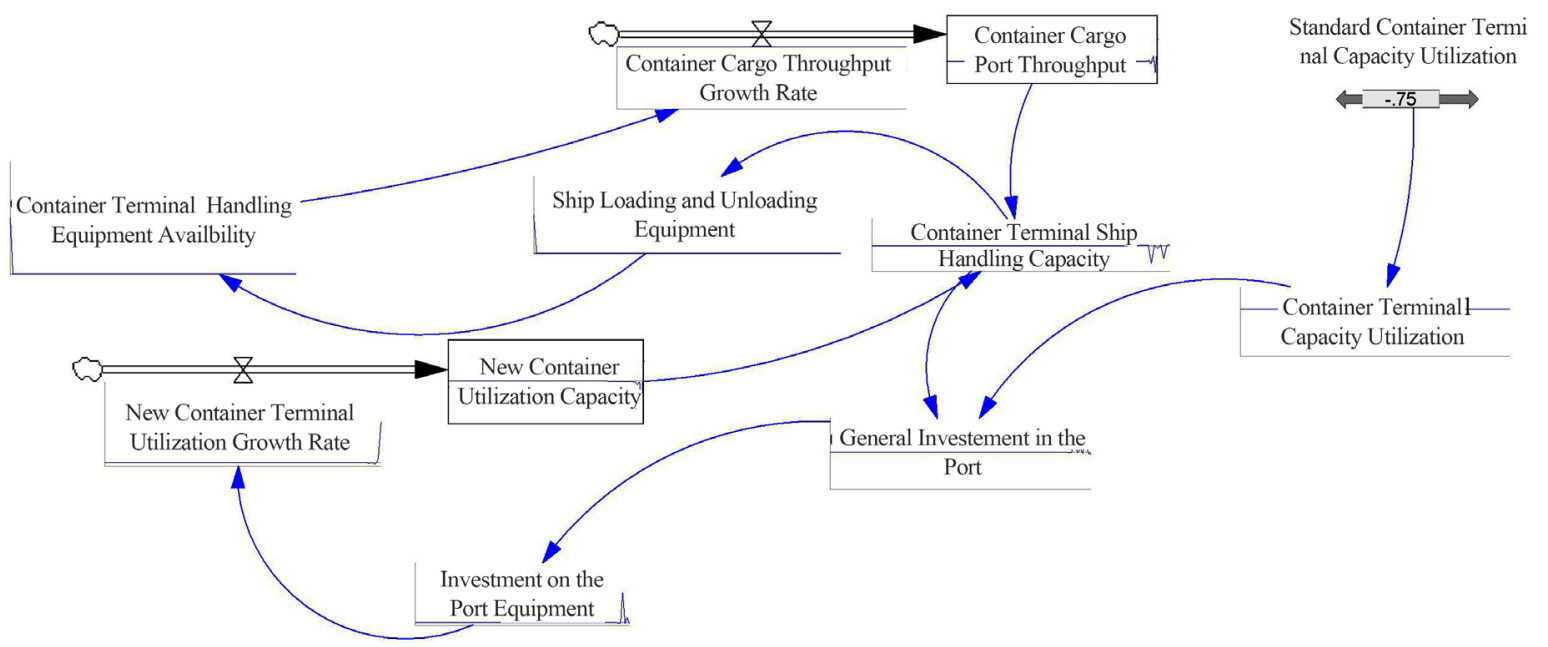

(a)

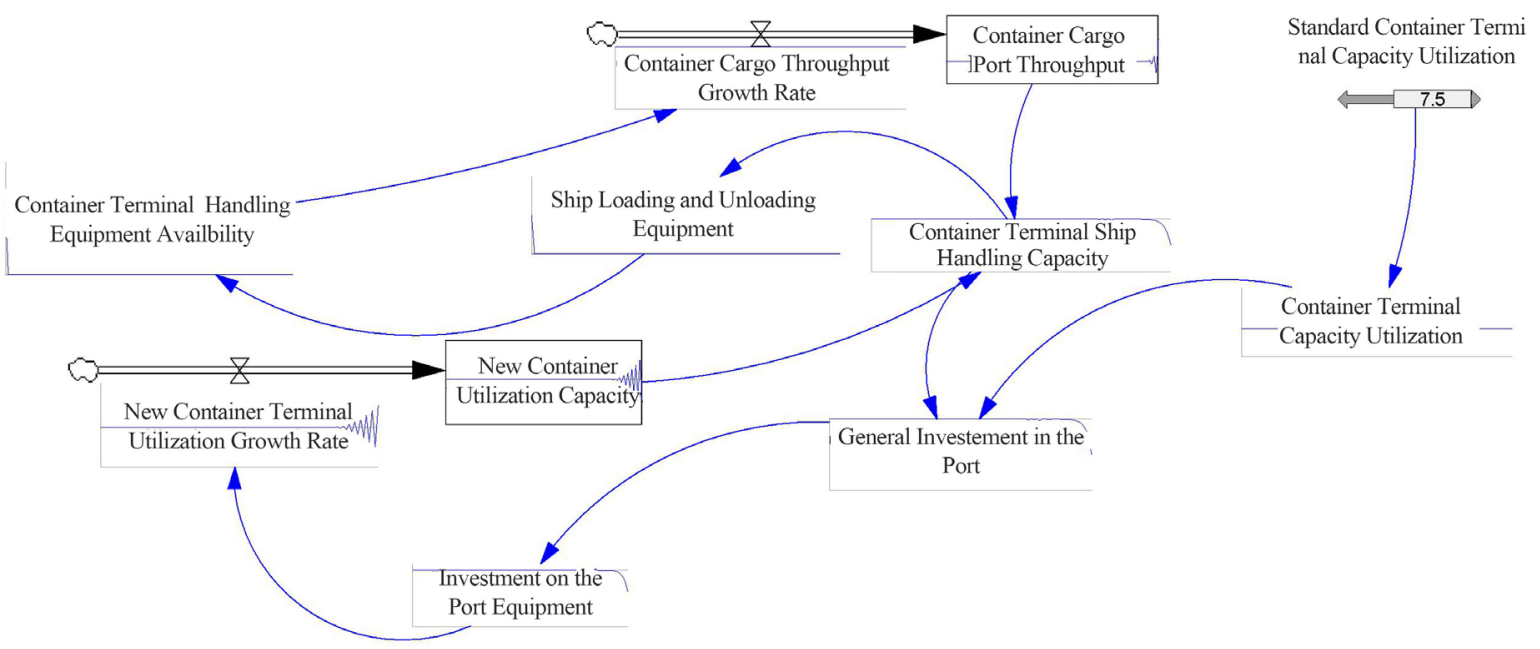

(b)

Figure 2. (a) Container terminal capacity; (b) Container terminal capacity.

Concerning Owendo port we can see that his data are almost similar to Douala port (Cameroon) (Table 2), the need for investment on port equipment's or general investment on the port, makes us use the Vensim's built-in function to the model delay. Because the investment in the port terminal is not immediate, and this process takes into consideration the time investors decide to invest after negotiations and the time to get authorization for the building process to start.

In Gabon, the decision for investment on terminal capacity took three years including all processes to start the building work, because it was a public and private investment. As we mentioned previously, the congestion level reflects the port quality service, the port demand growth rate usually depends on the terminal capacity availability, which depends too on the port congestion.

The fact that the demand of a port takes some time to be adjusted with the quality of service provided by the port authority, the function delay is used in the model for Gabon port, knowing that the container cargo throughput growth rate is, the same as container cargo port throughput itself. 
With all this, we can assume base on the result of the Vensim's model that the terminal capacity takes in consideration other factors, where they can have different capacity because the real capacity is always imposed. Let say the lowest value, the model assumes that new investment will be made for the other factors to bring their capacity up to the highest existing value to avoid the situation of wasted capacity.

For this to be done, the model helps us to compare the actual installed capacity for each factor with the maximum installed capacity and give us the limit of highest investment as a reflection of the highest level of investment that can be made for Gabon case.

\subsection{Handling Price}

The price charged by the port terminal for the loading and unloading is determined by the dwell time, also knowing that the port demand is not only affected by its capacity but also with other general external factors like port fees charge.

Port capacity is determined by the cargo dwell time, which reflects the price charged by the port terminal operators for the facilities and services they provide.

The port demand is influenced by the total port cost which is charged by the terminal operators to the ship owner and owner of containers cargos.

Cargo owner allows making a comparison between the current exact container price at the terminal and reference price of containers storage at the terminal is the result of the dwell time variation.

We can also say that when exact container price at the terminal increase then container dwell time should generally be decreasing, but when the exact container price at the terminal decrease then container dwell time to increase, and it makes cheaper to use the port facilities for even storage or others reasons (Figure 3(a)).

When the exact container storage price at the terminal increase from 0.1 to a high price, the factors that are: difference in container storage price at the terminal, the impact of port price on container dwell time and container dwell time, also increase to the same direction at the same moment, when it decreases, all those factors mentioned also decrease to at the same moment (Figure 3(b)).

The factors which are: difference in container storage price at the terminal, the impact of port price on container dwell time and container dwell time estimation, decrease at the same time almost reach 0 (Figure $4(a)$ ) when the reference storage price of the container terminal increase from 0.1 to a high number. When the factors which are the difference in container storage price at the terminal, the impact of port price on container dwell time and container dwell time estimation, increase at the same moment (Figure 4(b)), the reference price of container storage at the terminal decrease from a high number to 0 .

\subsection{Dwell Time}

However, for the container dwell time, it assumes base on the result of the model 
building that is playing a role in the port terminal process which can affect his performance base on the port authority management policy. The container dwells time estimation is the mirror of the container dwell time in the fact that it reflects the reality on the port charge (Figure 5(a), Figure 5(b)).

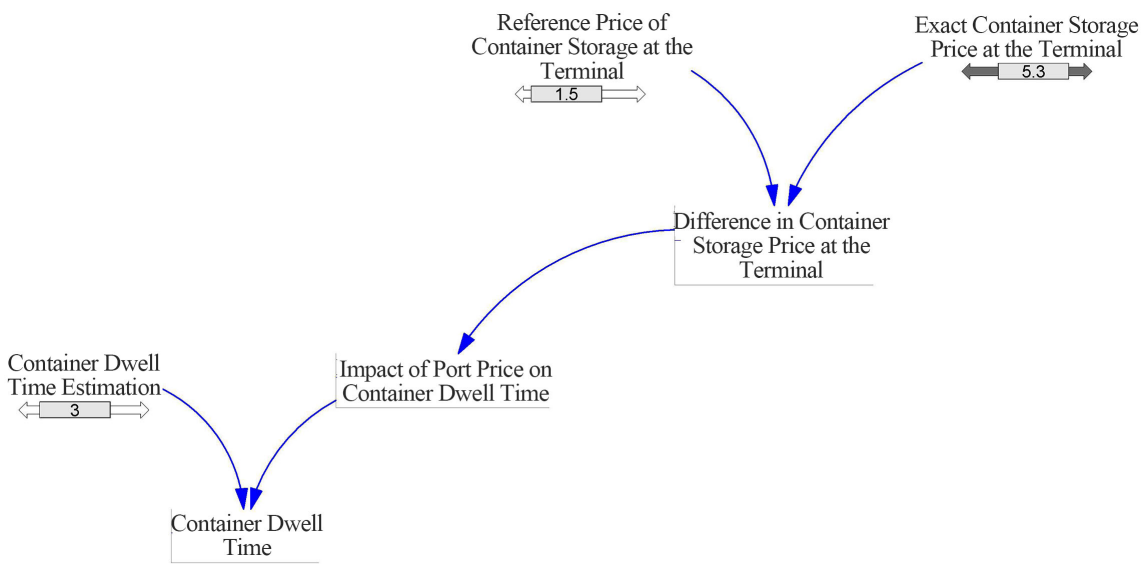

(a)

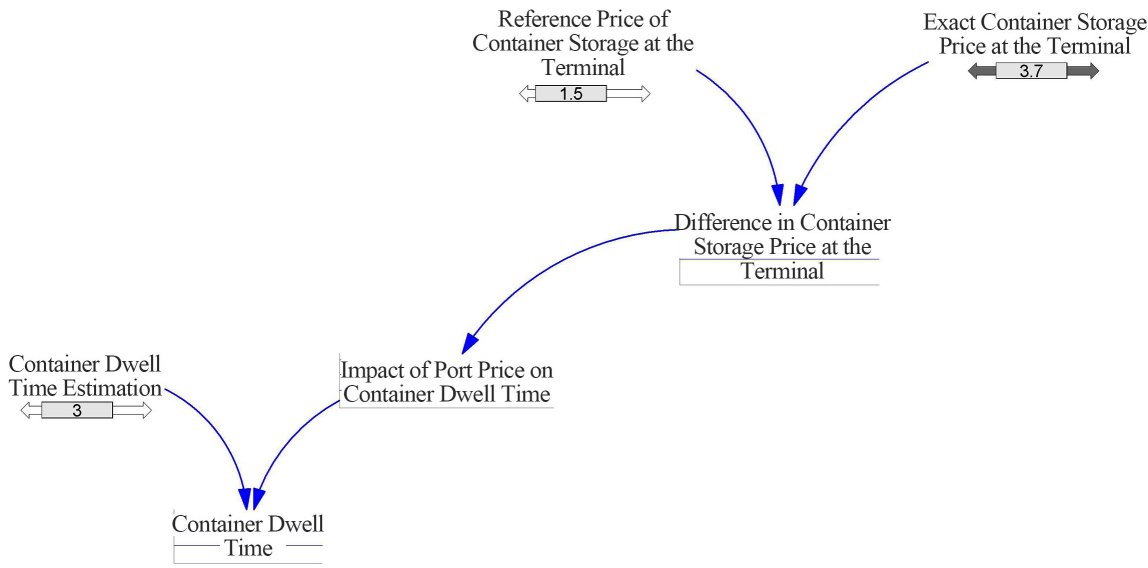

(b)

Figure 3. (a) Impact of handling price; (b) Impact of handling price.

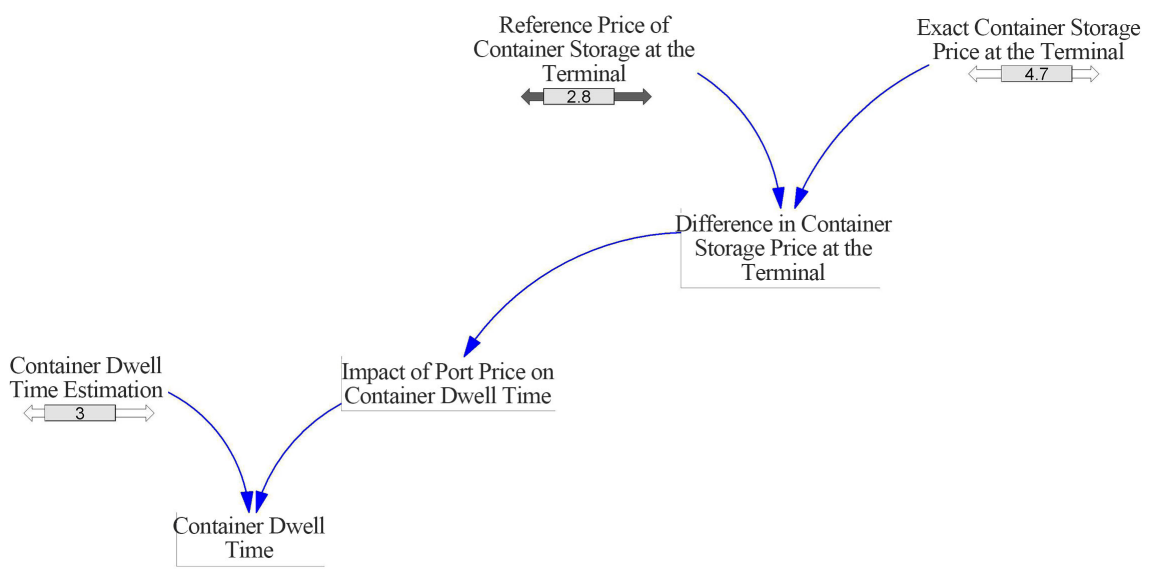

(a) 


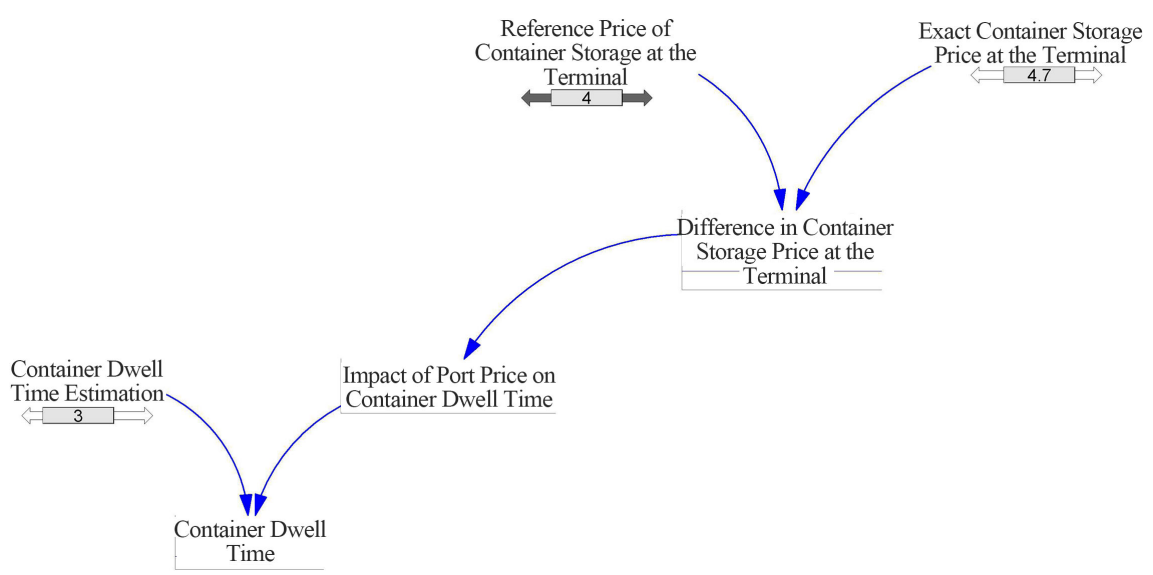

(b)

Figure 4. (a) Port fees charges; (b) Port fees charges.

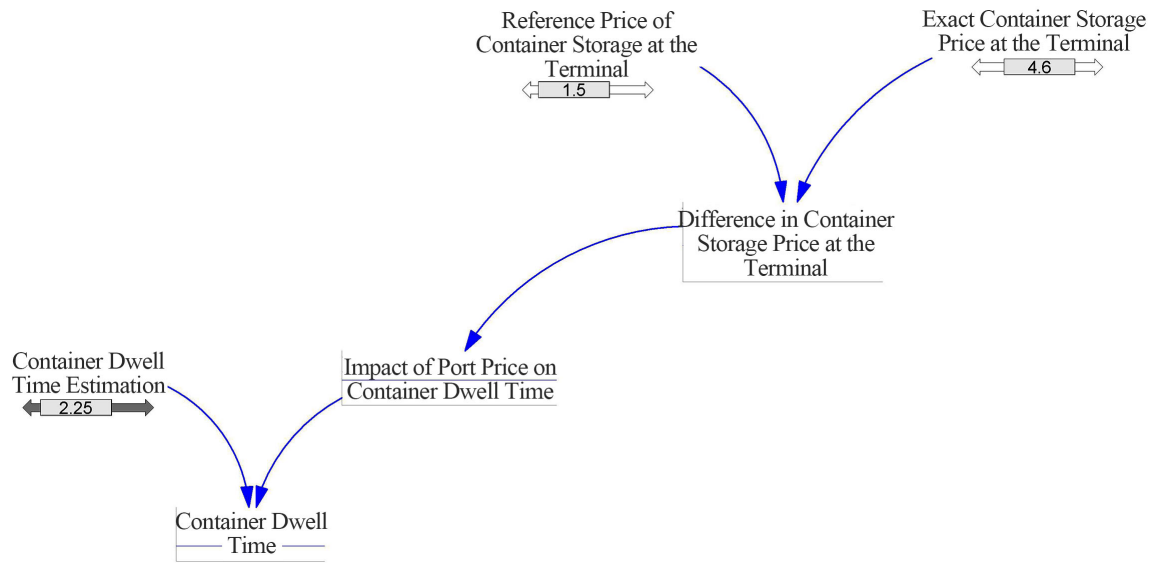

(a)

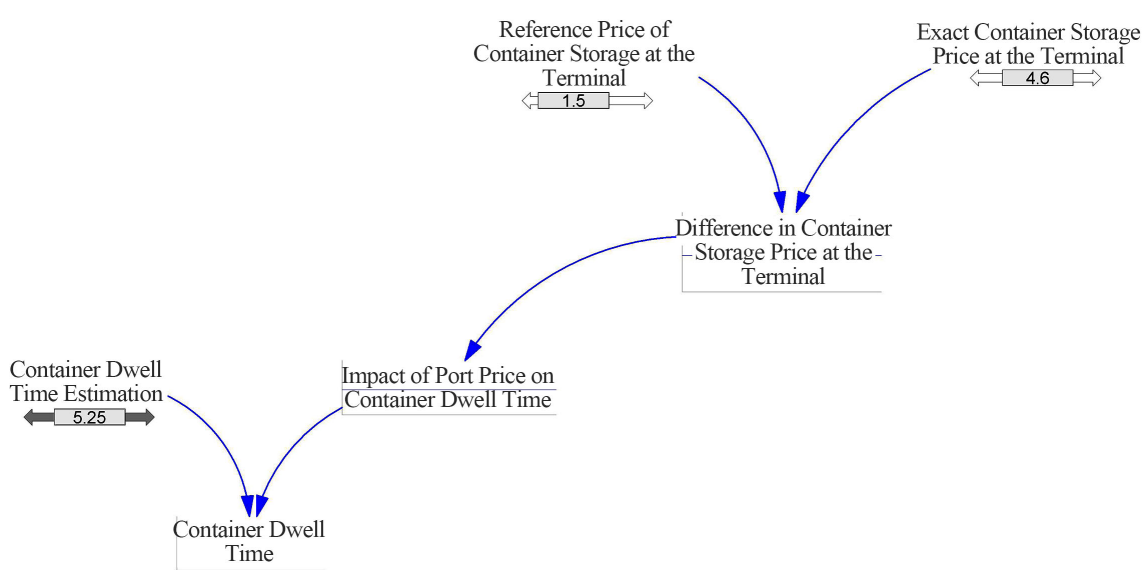

(b)

Figure 5. (a) Container dwell time; (b) Container dwell time.

\section{Recommendations}

After going through our study, we realised that the maritime industries are a sector where today all African ports are taking part of the competition to be 
profitable, which means new investments are always put in and the management strategies always adjusted for them to still to be competitive like what our paper is suggesting for Owendo port.

$>$ The current performance of Owendo port has been made base on the actual situation, after new investment and organisation of the management Owendo port will get more arguments with his potential to become a gateway port and will have more traffic and challenge to face like the network system connectivity in the region of CEMAC and huge challenges of logistics traffic trading between the countries.

$>$ The facilities of productions of free trade zone of NKOK will attract more investors and will increase his level of goods production for export that will be an news challenge and it will need a synchronize system of logistics and customers process for the goods to be transports by seeing for international market on time, which actually doesn't really exist because Gabon export until recent years just natural resource and just start recently with semi-finish and finish goods export for international market.

> The globalisation of the maritime world industries is forced all the ports around the world to be adjusting their infrastructures to be able to take part in the maritime traffic, which Gabon port authorities should adopt as a new politics on long term investment with public and private sectors industries to be competitive. All the time due to the evolution of the maritime industries and the fact that in the region of CEMAC 4 of the 6 countries members has at least one major port.

$>$ The natural constraints that Owendo port is facing today for his expansion due to his geographic location should remind the Gabonese government to put back on the table the project of the construction of the port of Mayumba in deep water, which will take in consideration all the challenge of the world maritime industry like the reception of very big ship like PANAMAX during his construction that most of the African ports are facing.

\section{Conclusion}

The main objectives of our study were first to measure the efficiency of Owendo port of Gabon and compare it to the Douala port of Cameroon, which gives us an idea about the efficiency of the performance at Owendo port by using DEA. The second objective is the use of System Dynamic to help us to build a model to understand the management of new investment in the port of Owendo to increase his container throughput and improve his services, and profits also for the port to become a gateway port.

DEA is often used to study the port efficiency by measuring the way container ports perform. For that measurement, we need to consider some inputs and outputs similar to each of the ports and in our case, the measurement of Owendo port of Gabon efficiency has been done compared with five other ports, which gives us a total of six ports from the west and central Africa where 
Owendo port of Gabon can plan to become a gateway port of central Africa.

The first step of our study was conducted by measuring the current efficiency of Owendo port and comparing its position with Cameroon port with four other ports. We selected some ports among West and Central African ports, with the same characteristics, taking their container throughput, terminal area, berth length, reach stackers into consideration.

The result came out with Douala port of Cameron as the most efficiency port over the five others ports from the west, and central Africa and Gabon port came on the third position when port like Apapa (Nigeria), with the large size and throughput, came on the four positions with a percentage of $0.94 \%$.

Focusing on our principal objective which is to compare the efficiency between Douala port of Cameroon and Owendo port of Gabon, we can assume based on the result that Douala port of Cameroon is performing better than Owendo port of Gabon and also that, Owendo port of Gabon is performing better than Apapa port (Nigeria), which is the large size and throughput port selected for our study. Based on that, we now have a fair idea of the level of investment Owendo port of Gabon needs to make for its investment and also the specific sectors invested in.

Using System Dynamic, it was also essential to see how each factor is connecter to have an idea about how to improve the port efficiency, and for the port to use its capacity efficiency which will improve the services provided by Owendo port (Gabon).

System Dynamic model suggests that the port investment is not only to anticipate in future demand and activity but also to improve the efficient management of the Owendo port (Gabon). However, it is more effective to increase the port throughput most of the time rather than to improve the management.

The model makes us understand that the impact of the investment does not only depend on the level of investment but also the policy applied like storage price, port fees, and the qualities of services provided. Also, the decision of the level of investment must consider the natural constraint of the port capacity. The result of the model build shows that the port demand reflects the port price, which means that fee charges are playing a significant role in the port activities, and its capacity is directly related to the port price.

Finally, we can say that several assumption or interpretation could be made using System Dynamic for the future investment of Owendo port which also requires more confidential data to use it and get the accurate results. However, it can also be submitted to the expert of the maritime field to analysis for the appreciations.

Using System Dynamic in our case gives us an idea about what to consider if Owendo port (Gabon) should make a new investment to pretend to become a gateway port of central Africa. The use of this model has also made the opportunities and capacities for the Owendo port (Gabon) to become a gateway port. 


\section{Conflicts of Interest}

The authors declare no conflicts of interest regarding the publication of this paper.

\section{References}

Bichou, K. (2013). An Empirical Study of the Impact of Operating and Market Conditions on Container Port Efficiency and Benchmarking. Research in Transportation Economics, 42, 28-37. https://doi.org/10.1016/j.retrec.2012.11.009

Cullinane, K., \& Wang, T. F. (2007). Devolution Port Governance and Port Performance. Research in Transportation Economics, 17, 517-566. https://doi.org/10.1016/S0739-8859(06)17023-7

Cullinane, K., Wang, P., \& Cullinane S. L. (2004). Container Terminal Development in Mainland China and Its Impact on the Competitiveness of the Port of Hong Kong. Transport Review, 24, 37-56. https://doi.org/10.1080/0144164032000122334

Cullinane, S. D. W., Ji, P., \& Wang, T. F. (2004). An Application of DEA Windows Analysis to Container Port Production Efficiency. Review of Network Economics, 3, 184-206. https://doi.org/10.2202/1446-9022.1050

Gi-tae, Y., Micheal, R., \& John, D. (2011). Measuring Competitiveness of Container Port Logisticians Perspectives European. Journal of Marketing, 45, 457-470. https://doi.org/10.1108/03090561111107276

ISEMAR (2016). Terminalisation Specialisation et Enjeux Logistiques des Ports Africains. ISEMAR No. 179.

Kingsleychenikwi, C., \& Wang, X. (2018). The Hub Status and Transportation Network of Kribi Port. Open Journal of Applied Sciences, 8, 226-270. https://doi.org/10.4236/ojapps.2018.86019

Leki Port (2014). http://lekkipart.com/theport/keyfacilities.html

Li, D., \& Wang, X. (2013). System Dynamics Simulation Model for Port Economy Analysis. In J. Xu, M. Yasinzai, \& B. Lev (Eds.), Proceedings of the Sixth International Conference on Management Science and Engineering Management. Lecture Notes in Electrical Engineering (Vol. 185). London: Springer. https://doi.org/10.1007/978-1-4471-4600-1_41

Martin, J., \& Roman, C. (2001). An Application of DEA to Measure the Efficiency of Spanish, Airport Priority to Privatization. Journal of Air Transport Management, 17, 149-157. https://doi.org/10.1016/S0969-6997(00)00044-2

Miguel, A. (2012). Analysis of Investment Policies for the Ports of Lisbon with s System Dynamic Model. Master's Degree, Thesis, Universidad Tecnica de Lisboa.

Min, H., \& Park, B. (2008). Evaluation of the Inter-Temporal Efficiency Trends of International Container Terminal Using Data Development Analysis. International Journal of Integrated Supply Management, 1, 258-277. https://doi.org/10.1504/IJISM.2005.005950

Notteboom, T. (2010). Concentration the Formation of Multi-Port Gateway Region in the European Container Port System. An Update Journal of Transport Geography, 18, 567-583. https://doi.org/10.1016/j.jtrangeo.2010.03.003

Park, N., \& Lim, C. (2012). Port Choice Model of Transshipment Cargo Using System Dynamic. In Maritime Logistics (pp. 69-90). Bingley: Emerald Group Publishing Limited. https://doi.org/10.1108/9781780523415-005

Richardson, G. P. (2011). Reflection on the Foundation of System Dynamic. System Dy- 
namic Review, 27, 219-243. https://doi.org/10.1002/sdr.462

Rodrigue, J.-P., \& Guan, C. Q. (2009). Port Hinterland Divergence along the North America Eastern Seaboard. In T. Notteboom, C. Ducruet, \& P. De Langen (Eds.), Ports in Proximity: Competition and Coordination among Adjacent Seaports, Surrey: Ashgate (pp. 131-150).

Roll, Y., \& Hayuth, Y. (1993). Port Performance Comparison Applying Data Envelopment Analysis (DEA). Maritime Policy \& Management, 20, 153-161. https://doi.org/10.1080/03088839300000025

Schøyen, H., \& Odeck, J. (2013). The Technical Efficiency of Norwegian Container Ports: A Comparison to Some Nordic and UK Container Ports Using Data Envelopment Analysis (DEA). Maritime Economics \& Logistics, 15, 197-221. https://doi.org/10.1057/mel.2013.3

Sterman, J. (2011). Sustainability: Creating Systems Sciences in a Framended Academic and Polarized World. MIT Sloan School of Management. https://doi.org/10.1007/978-1-4614-3188-6_2

Suryani, E. (2012). Dynamic Simulation Model of Air Cargo Demand Forecast and Terminal Capacity Planning. Simulation Modelling Practice and Theory, 28, 27-41. https://doi.org/10.1016/j.simpat.2012.05.012

Tabernacle, J. (1995). A Study of Changes in Performance Comparison Applying Data Analysis (DEA). Maritime Policy and Management, 20, 153-161. https://doi.org/10.1080/03088839300000025

Tongzon, J. L. (1995). Determinants of Port Performance and Efficiency. Transportation Research Part A: Policy and Practice, 29, 245-252. https://doi.org/10.1016/0965-8564(94)00032-6

Van Dyck, G. (2015). Assessment of Port Efficiency in West Africa Using Data Envelopment Analysis. American Journal of Industrial and Business Management, 5, 208-218. https://doi.org/10.4236/ajibm.2015.54023 